\title{
PERANAN GURU PENDIDIKAN AGAMA ISLAM DALAM MENGATASI KESULITAN PESERTA DIDIK MEMBACA AL-QUR'AN DI SMP NEGERI 3 TANIWEL KECAMATAN TANIWEL BARAT KABUPATEN SERAM BAGIAN BARAT
}

\author{
Rini Assel \\ Program Studi Pendidikan Agama Islam FITK IAIN Ambon' \\ email: asselrini014@gmail.com.
}

\begin{abstract}
The purpose of this study was to determine the role of Islamic religious education teachers in overcoming the difficulties of students reading the Qur'an at SMP Negeri 3 Taniwel, West Taniwel District, West Seram Regency. The type of research is descriptive qualitative research. The results of the study indicate that the role of Islamic religious education teachers in overcoming the difficulties of students reading the Koran at SMP Negeri 3 Taniwel includes; a. The teacher as a teacher, the role of the teacher as a coach, the teacher as an example. Factors supporting the implementation of the duties or roles of Islamic religious education teachers are facilities and infrastructure (learning media), teacher awareness in carrying out responsibilities and student learning motivation. Inhibiting factors are the lack of time allocation and lack of parental attention.
\end{abstract}

Keywords: Islamic Religious Education, Difficulty Reading The Qur'an.

Abstrak: Tujuan penelitian ini untuk mengetahui peranan guru pendidikan agama Islam dalam mengatasi kesulitan peserta didik membaca al-Qur'an di SMP Negeri 3 Taniwel Kecamatan Taniwel Barat Kabupaten Seram Bagian Barat. Tipe penelitian adalah penelitian deskriptif kualitatif. Hasil penelitian menunjukkan bahwa peranan guru pendidikan agama Islam dalam mengatasi kesulitan peserta didik membaca al-Qur'an SMP Negeri 3 Taniwel meliputi; a. Guru sebagai pengajar, Peran guru sebagai pelatih, Guru sebagai teladan. Faktor pendukung pelaksanaan tugas atau peranan guru pendidikan agama islam adalah Sarana dan prasarana (media pembelajaran), Kesadaran guru dalam melaksanakan tanggung jawab dan Motivasi belajar peserta didik. Faktor penghambat yakni Kurangnya alokasi waktu dan Kurangnya perhatian orang tua.

Kata kunci: Mata Pelajaran PAI, Kesulitan Membaca AI-Qur'an.

\section{PENDAHULUAN}

Diantara kemurahan Allah terhadap manusia bahwa Dia tidak saja memberikan sifat yang bersih yang dapat membimbing dan memberi petunjuk kepada mereka kearah kebaikan, tetapi juga dari waktu ke waktu Dia mengutus seorang rasul kepada umat manusia dengan membawa alKitab dari Allah dan menyuruh mereka beribadah hanya kepada Allah saja, menyampaikan kabar gembira dan memberikan peringatan (Manna' Khalil al-Qattan, 2004:10). 
Perkembangan dan kemajuan berpikir manusia senantiasa disertai oleh penurunan wahyu yang sesuai dan dapat memecahkan problemproblem yang dihadapi oleh kaum setiap rasul saat itu, sampai perkembangan itu mengalami kematangannya. Allah menghendaki agar risalah Muhammad saw. muncul di dunia ini. Maka diutuslah beliau di saat manusia sedang mengalami kekosongan para rasul, untuk menyempurnakan "bangunan" saudara-saudara pendahulunya (para rasul) dengan syari'atnya yang universal dan abadi serta dengan kitab yang diturunkan kepadannya, yaitu al-Qur'anul Karim (Manna' Khalil alQattan, 2004:10).

Kitab-kitab sebelum al-Qur'an diturunkan pada kaum tertentu dan zaman tertentu. Sedangkan al-Qur'an diturunkan untuk seluruh umat manusia di bumi untuk waktu yang tidak dibatasi. Inilah salah satu hal yang paling membedakan kitab sebelumnya dengan al-Qur'an.

al-Qur'an diturunkan kepada Muhammad dengan sangat luar biasa untuk diajarkan kepada semua umatnya. Isi al-Qur'an akan tetap. Jumlah huruf, ayat,dan apa yang termuat di dalamnya akan tetap. Tidak akan bertambah dan tidak akan berkurang. Apa yang menjadi isinya pun akan tetap sama.

Banyak hal yang membuat al-Qur'an menjadi luar biasa. Dinamis yang dimiliki dalam al-Qur'an bukanlah isinya yang dapat berkurang atau bertambah, tapi bagaimana sebuah pemahaman terhadap sebuah huruf maupun rangkaian kata dalam kitab ini di terjemahkan oleh manusia sebagai pedoman kehidupan manusia yang terus bergerak tiada henti.

Kitab umat Islam yang sangat istimewa ini tidak dapat kita rasakan keistimewaannya dan kita ambil manfaatya jika kita tidak bisa membacanya dan memahaminya. Dalam qur'an surat al-Alaq ayat 3-5 Allah berfirman:

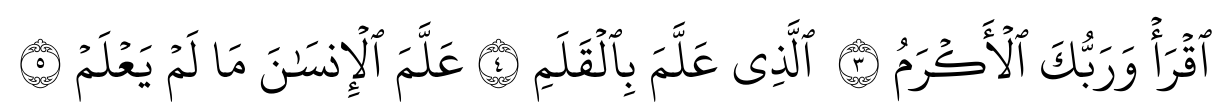


Artinya: "Bacalah, dan Tuhanmulah Yang Maha Pemurah. Yang mengajar (manusia) dengan perantara kalam. Dan dia mengajarkan kepada manusia apa yang tidak diketahuinya"

Ayat ini menunjukkan bahwa, manusia tanpa melalui belajar tidak akan dapat mengetahui segala sesuatu yang ia butuhkan bagi kelangsungan hidupnya di dunia dan di akhirat. Pengetahuan manusia akan berkembang jika diperoleh melalui proses belajar mengajar yang diawali dengan kemampuan baca tulis dalam arti luas, yaitu tidak hanya dengan membaca tulisan melainkan juga membaca segala yang tersurat maupun yang tersirat di alam raya ini melalui ketajaman akal fikiran sebagai dari tujuan penciptaannya.

Untuk menggunakan Al-Qur'an sebagai pedoman bagi kehidupan manusia maka ada beberapa tahapan untuk mencapai hal tersebut. Pertama, yaitu kemampuan untuk membaca. Kedua, memahami, dan yang terakhir adalah mengikuti (Iris Gunawan Hasim, 2008:16).

Membaca, adalah langkah awal untuk semua umat Islam dalam menggunakan Al-Qur'an sebagai pedoman hidup. Dari membaca kita akan menjadi tahu, dari tahu kita menjadi paham, dan dari pemahaman tersebut kita dapat mengaplikasikannya dalam kehidupan sehari-hari. Telah disebutkan bahwa membaca yang dimaksud bukan hanya sekedar membaca tanpa ada tindak lanjut. Tapi membaca dengan usaha untuk memahami apa yang sedang kita baca. al-Qur'an harus dipandang oleh umat Islam sebagai pedoman yang mencakup keseluruan aspek tentang kehidupan, bukan hanya yang bersifat religius tapi juga ilmu pengetahuan serta ekonomi. Kitab ini juga dapat mengeluarkan atau menyelamatkan manusia dari macam-macam perselisihan dan percekcokan antara satu golongan dengan golongan yang lain (Moenawar Khalil, 1985:172).

Bagi umat Islam membaca al-Qur'anul karim merupakan satu perbuatan yang mulia. Bahkan melalui sabda rasul-Nya dinyatakan bahwa dengan membaca al-Qur'an maka akan mendapatkan pahala yang berlipat. Bukan dinilai dari banyaknya ayat atau kata yang dibaca, tetapi 
akan mendapat pahala pada setiap huruf yang dibaca. Apalagi jika dibaca dalam waktu-waktu utama (Yunus Hanis Syam, 2008:38).

Remaja di Indonesia kebanyakan melakukan bacaan rutin ayat suci Qur'an ketika mereka masih kecil atau masih duduk di tingkat Sekolah Dasar. Dan begitu mereka semakin beranjak remaja dan dewasa, banyak dari mereka akan mengutamakan hal-hal lain yang berkaitan dengan sosial, lingkungan, maupun perihal sekolah mereka. Dan kegiatan rutin mengaji akan terabaikan. Hal ini akan dapat diperparah jika tempat tingal peserta didik ataupun keluarganya membiarkan hal ini terus berlanjut dan mereka mempunyai fikiran bahwa nilai akademik sekolah amat sangat penting dari pada hanya belajar mengaji (Yunus Hanis Syam, 2008:37).

Rumusan tujuan pendidikan Islam adalah merealisasikan manusia muslim yang beriman, bertaqwa, dan berilmu pengetahuan yang mampu mengabadikan dirinya kepada Sang Khaliq dengan sikap dan kepribadian bulat menyerahkan diri kepada-Nya dalam segala aspek kehidupan dalam rangka mencari keridhannya-Nya (Abdullah, 2011:61-62).

Secara sosiologis, pendidikan merupakan salah satu institusi pokok dalam masyarakat. Pertama, keluarga yang menjaga dan membimbing generasi muda atau peserta didik agar menjadi mandiri. Kedua, ekonomi yang berfungsi menghasilkan dan mendistribusikan barang-banrang. Ketiga, pemerintah yang berfungsi memberi dan melindungi masyarakat. Keempat, agama yang befungsi menjawab permasalahan spiritual. Kelima, pendidikan yang berfungsi mendidik masyarakat. Dalam hal ini, pendidikan memiliki peranan strategis dalam mencerdaskan masyarakat dan memajukan peradaban suatu bangsa (Abdullah, 2011: 363).

Sekolah merupakan lembaga pendidikan formal yang sedikit banyak membentuk karakter seorang peserta didik. Teman, lingkungan sekolah, guru, kepala sekolah, maupun kebijakan-kebijakan yang ada di sekolah akan berpengaruh terhadap peserta didik. Guru mempunyai tugas yang berat dalam proses pendidikan di sekolah. Karena guru berinteraksi secara langsung dengan para peserta didik di kelas saat melakukan 
pengajaran, yang hal ini akan secara langsung berdampak bagi individu peserta didik oleh karena itu, seorang guru tidak cukup hanya sekedar transfer of knowledge (memindahkan ilmu pengetahuan) dari luarnya saja, tapi juga transfer of value (memindahkan nilai) dari sisi dalamnya. Perpaduan dalamdan luar inilah yang akan mengkokohkan bangunan pengetahuan, moral, dan kepribadian peserta didik dalam menyongsong masa depannya (Jamal Ma'mur Asmani, 2013: 77-78). Karena tugas guru adalah mengajar sekaligus mendidik, maka keteladanan dari seorang guru menjadi harga mati yang tidak bisa ditawar-tawar. Keteladanan merupakan senjata mematikan yang sulit untuk dilawan. Keteladanan adalah suatu yang dipraktikkan, diamalkan bukan hanya dikhutbahkan, diperjuangkan, diwujudkan dan dibuktikan (Jamal Ma'mur Asmani, 2013: 79).

Peran guru berkaitan dengan bagaimana seorang guru mampu memahami dan menentukan batasan-batasan yang harus dilakukan oleh seorang peserta didik dalam mengorganisasikan materi, berinteraksi, dan melakukan proses-proses pembelajaran. Guru sebagai pendidik profesional perlu memiliki pengetahuan yang bersifat baik tentang perkembangan kognitif peserta didiknya. Dengan bekal tersebut, guru dapat melaksanakan proses pembelajaran yang sesuai dengan kemampuan berpikir peserta didiknya (Novan Ardy Wijaya, 2014: 81). Hal ini sebagaimana diungkapkan oleh guru PAI bahwa:

Dalam mengatasi peserta didik yang tidak bisa membaca al-Qur'an tidaklah mudah dan segampang apa yang kita pikirkan, karena peserta didik zaman sekarang dituntut untuk bisa membaca alQur'an dengna baik dan benar sesuai makhraj huruf namun terkadang sulit untuk dilakukan peserta didik. Oleh karena itu saya selaku guru PAI di SMP Negeri 3 Taniwel memotivasi peserta didik agar peserta didik mau belajar membaca al-Qur'an dengna baik dan benar selain di sekolah pun di rumah juga harus belajar karena al-Qur'an adalah pedoman hidup bagi umat Islam secara keseluruhan. Olehnya itu, peran yang saya lakukan yang pertama melalui materi PAI di sekolah karena pendidikan agama Islam bertujuan untuk membimbing peserta didik agar mereka menjadi muslim sejati, membentuk pribadi muslim beriman teguh dan 
bertaqwa kepada Allah Swt, beramal shaleh dan berakhlak mulia serta berguna bagi masyarakat agama dan negara. Untuk memiliki kepribadian muslim diperlukan pengetahuan dan pemahaman tentang al-Qur'an dan Hadits sangat penting bagi umat Islam pada umumnya dan bagi peserta didik pada khususnya. al-Qur'an dan Hadits sebagai pedoman hidup umat Islam, hendaknya sudah diajarkan sejak dini, baik di rumah, sekolah maupun masyarakat. (Wawancara dengan sarika pulu, Guru PAI SMP Negeri 3 Taniwel. 12 Maret 2019)

Hal ini juga terjadi di SMP Negeri 3 Taniwel. Kecamatan Taniwel Barat, Kabupaten Seram Bagian Barat. Pengajaran PAI disana tidak hanya dituntut untuk dapat membaca tapi juga memahami bacaan Qur'an tersebut sehingga peserta didik mampu dalam membaca al-Qur'an. Para peserta didik di SMP Negeri 3 Taniwel Kecamatan Taniwel Barat Kabupaten Seram Bagian Barat ini mepunyai tingkat kemampuan membaca yang berbeda-beda. Dari observasi yang penulis lakukan, maka ditemukan peran guru guru berperan sebagai pengajar dalam hal mengajarkan materi al-Qur'an kepada peserta didik dengan memberikan arahan dan latihan membaca kepada peserta didik untuk membaca alQur'an sesuai dengan lafal yang baik dan benar sesuai makhraj huruf. Selain itu guru juga berperan sebagai pembimbing hal ini dilakukan guru ketika masih ada peserta didik yang salah dalam membaca al-Qur'an sehingga guru membimbing peserta didik tersebut agar membacanya berlahan sambil mengarahkan agar bacaan yang dibaca menjadi benar. (Hasil Observasi Partisipan, 11 Maret 2019)

Dari latar belakang permasalahan tersebut di atas, maka peneliti tertarik untuk melakukan penelitian dengan judul "Peranan Guru Pendidikan Agama Islam Dalam Mengatasi Kesulitan Peserta didik Membaca al-Qur'an di SMP Negeri 3 Taniwel Kecamatan Taniwel Barat Kabupaten Seram Bagian Barat". 


\section{METODE}

Penelitian ini, menggunakan metode kualitatif deskriptif yang berusaha mengerti dan memahami kejadian/peristiwa dalam situasi tertentu yang Nampak (Lexi. J. Moloeng, 2009:10). Pendekatan ini digunakan dalam mengumpulkan data mengenai peranan guru pendidikan agama Islam dalam mengatasi Kesulitan peserta didik membaca AlQur'an di SMP Negeri 3 Taniwel Kecamatan Taniwel Barat Kabupaten Seram Bagian Barat.

\section{HASIL}

\section{Peranan guru pendidikan agama Islam dalam mengatasi kesulitan peserta didik membaca al-Qur'an di SMP Negeri 3 Taniwel \\ Kecamatan Taniwel Barat, Kabupaten Seram Bagian Barat}

Temuan khusus deskripsi ini berkenaan dengan hasil penelitian ini disusun berdasarkan hasil observasi/pengamatan langsung yang dilakukan peneliti selama berada di lokasi penelitian yaitu SMP Negeri 3 Taniwel Kecamatan Taniwel Barat Kabupaten Seram Bagian Barat, maka dapat disimpulkan bahwa tentang fasilitas sarana dan prasaran SMP Negeri 3 Taniwel sudah dapat dikatakan cukup baik, hanya saja fasilitas berupa komputer belum seimbang dengan keadaan peserta didik. kemudian berdasarkan jawaban atas pertanyaan-pertanyaan yang diberikan oleh peneliti terhadap Narasumber melalui kegiatan wawancara yang dilakukan terhadap pihak terkait dan disusun berdasarkan jawaban atas pertanyaan dalam penelitian melalui wawancara dan pengamatan secara langsung di lokasi penelitian.

Dari observasi yang dilakukan oleh peneliti menunjukkan bahwa keadaan dan letak SMP Negeri 3 Taniwel Kecamatan Taniwel Barat Kabupaten Seram Bagian Barat sangatlah strategis karena jauh dari jalan raya dan tempat keramaian kemudian mudah dijangkau dengan berjalan kaki. Keadaan sekolah juga terlihat sangat strategis dan bersih terlihat dari jumlah bangunan yang terdiri dari tujuh ruang kelas. Sekolah ini termasuk 
lembaga pendidikan yang melaksanakan proses belajar mengajar pada pagi dan dimulai pada pukul 07.00 WIB dan diakhiri pada pukul 12. 40 WIB.

Peranan guru Pendidikan agama Islam dalam mengatasi kesulitan peserta didik membaca al-Qur'an di SMP Negeri 3 Taniwel, Kecamatan Taniwel Barat Kabupaten Seram Bagian Barat. Berdasarkan hasil penelitian yang peneliti lakukan, maka ditemukan data peranan guru PAI dalam mengatasi kesulitan peserta didik membaca al-Qur'an di SMP Negeri 3 Taniwel Kecamatan Taniwel Barat Kabupaten Seram Bagian Barat sebagai berikut:

a) Guru sebagai pengajar

Berdasarkan hasil wawancara dengan Kepala Sekolah di SMP Negeri 3 Taniwel Kecamatan Taniwel Kabupaten Seram Bagian Barat:

Sebagai pengajar, guru Pendidikan Agama Islam menghadapi tanggung jawab yang berat, untuk itu ia harus memiliki persiapan dan potensi yang memadai guna tercapainya suatu hasil pendidikan yang maksimal terutama dalam membaca al-Qur'an. Guru Pendidikan Agama Islam sebagai pendidik adalah merupakan seseorang yang memberikan pelajaran dan menanamkan nilai-nilai moral kepada peserta didiknya agar bisa mengembangkan ilmu pengetahuan yang disesuaikan dengan kaidah-kaidah keislaman.

Selanjutnya peranan guru Pendidikan Agama Islam juga disampaikan oleh Guru PAI, menurutnya peranan guru PAI adalah membimbing dan mengarahkan peserta didik untuk membaca al-Qur'an yang baik. Hal ini sebagaimana diungkapkan oleh guru PAI bahwa:

Agar proses pembelajaran berlangsung agam Islam di sekolah berlangsung dengan baik terutama materi yang berkaitan dengan al-Qur'an, maka sebelumnya saya biasanya menugaskan untuk melatih membaca al-Qur'an di rumah agar ketika peserta didik di sekolah dalam belajar sudah dapat membaca dengan baik dan benar serta lancar. Selain itu, ketika di lingkungan masyarakat saya juga mengingatkan peserta didik agar rajin berlajar semua mata pelajaran di sekolah dan terutmaa mata pelajaran agama Islam tentunya ada materi yang berkaitan dengan al-Qur'an ataupun Hadist yang memungkinkan peserta didik untuk membaca ayat tersebut dan kemudian menghafalkannya karena jika diamalakan akan mendatangkan kebaikan dan pahala. 
Selain itu, guru PAl bertanggung jawab atas hasil kegiatan belajar peserta didik melalui interaksi belajar mengajar. Guru PAI di kelas selalu berusaha dan berupaya semampu mungkin agar proses belajar mengajar berjalan dan berhasil sesuai keinginan dan target guru terhadap peserta didik. Hasil diperkuat dengan hasil wawancara yakni:

Selaku guru PAI, saya selalu berusaha dengan menggunakan metode membaca al-Qur'an salah satunya yakni metode Qiraati yakni metode membaca secara langsung (tanpa dieja) dalam, hal ini saya selalu mengupayakan agar peserta didik membaca alQur'an secara langsung tanpa dieja dan dengan pendekatan teman sebaya (tutor sebaya) yakni peserta didik yagn dianggap sudah lancar membaca al-Qur'an membantu mengajarkan kepada peserta didik lain yang belum lancar membaca Al-Qur'an sehingga terjadin interaski dalam pembelajaran. dengan demikian, maka metode atau strategi yang digunakan diraa cukup efektif sehingga peserta didiuk dapat memahami pelajaran atau materi yang saya ajarkan. Selain itu saya mempengaruhi peserta didik dengan memberi motivasi, kematangan yaitu hubungan saya dengan peserta didik sehingga muncul rasa nyaman peserta didik saat mengikuti pembelajaran.

Berdasarkan penuturan guru tersebut terkait dengan peran guru sebagai pengjar, maka dapat disimpulkan bahwa guru PAI sudah melakukan peranannya dalam belajar yang berkaitan dengan pendidikan agama Islam terutama dalam pembelajaran yang berkenaan dengan materi al-Qur'an dimana selain proses pembelajaran di sekolah, guru PAI juga memberikan tugas belajar membaca dan menghafal materi al-Qur'an ketika peserta didik berada di rumah.

b) Peran guru sebagai pelatih

Untuk menjadi seorang pelatih yang berhasil, maka guru PAI menjalankan perannya sebagai pelatih dengan kemampuannya yang profesional dalam meningkatkan pemahaman peserta didik melalui pelatihan yang diberikan guru PAI berupa tugas yang dikerjakan di rumah maupun berupa evaluasi yang dilakukan sehabis belajar untuk melatih kemampuan peserta didik dalam membaca al-Qur'an sehingga kesulitan dalam membaca al-Qur'an dapat teratasi. Sebagaimana diungkapkan dari hasil wawancara bersama guru PAI sebagai berikut: 
Agar berhasil dalam memberikan pelatihan, maka sebagai guru sekaligus sebagai pelatih harus mengetahui dan memahami strategi dan metode yang tepat. Dalam kaitan ini pengalaman sebagai guru dapat dipergunakan dalam mendidikan dan melatih peserta didik dalam mengerjakan tugas dan hal-hal lainnya meskipun tidak selalu dibutuhkan untuk mencapai keberhasilan tapi minimal peserta didik tahu terkait dengan cara menulis al-Qur'an atau membaca al-Qur'an dengan baik dan benar serta hal lain berupa membuat tugas dengan baik dan benar pula. Jadi pada dasarnya saya harus menguasai materi tentang al-Qur'an dulu apabila ingin menjadi pelatih bagi peserta didik saya selain itu juga saya memberikan evaluasi sehabis proses belajar mengajar untuk menilai dan mengukur kemampuan peserta didik dalam peningkatan pemahan mereka, adapun tugas yang harus dikerjakan di rumah yang saya berikan kepada peserta didik.

Sejalan dengan penuturan guru PAI tersebut, maka sebagaimana diungkapkan oleh kepala sekolah terkait dengan peran guru sebagai pelatih bahwa:

Di sekolah ini saya selalu menekankan kepada dewan guru agar mampu mengimplementasikan semua kemampuan dan potensi yang dimiliki oleh guru khususnya berkaitan dengan proses pembelajaran. Hal saya tekankan karena bila guru dapat mengembangkan potensi berdasarkan kemampuan ilmu yang dimiliki maka akan berdampak positif bagi kemajuan sekolah terutama kemampuan peserta didik dari dari segi kognitif, afektif maupun psikomotoriknya terutama dalam hal latihan baik latihan soal, latihan keterampilan ataupun latihan berbasis keagamaan (belajar al-Qur'an, sholat dan lainnya) karena pelatihan dalam kegiatan pembelajaran membuat peserta didik jadi terampil kreatif.

Berdasarkan uraian pada hasil wawancara yang telah dikemukakan oleh guru PAI dan kepala sekolah tersebut, maka dapat disimpulkan bahwa proses pembelajaran memerlukan latihan ketrampilan, baik intelektual maupun motorik, sehingga menuntut guru untuk bertindak sebagai pelatih. Hal ini lebih ditekankan lagi karena tanpa latihan seorang peserta didik tidak akan mampu menunjukkan penguasaan kompetensi yang dikembangkan sesuai dengan materi standar. Oleh karena itu, guru harus berperan sebagai pelatih, yang bertugas melatih peserta didik sesuai dengan potensi masing-masing. 
c) Guru sebagai teladan

Guru sebagai tenaga pendidik yang tugas utamanya mengajar, memiliki karakteristik kepribadian yang sangat pengaruh terhadap keberasilan pengembangan sumber daya manusia. Kepribadian yang mantap dari sosok seorang guru akan memberikan teladan yang baik terhadap peserta didik maupun masyarakatnya, sehingga guru akan tampil sebagai sosok yang patut "digugu" (ditaati nasehat/ucapan/perintahnya) dan "ditiru" (dicontoh sikap dan perilakunya). Kepribadian guru fiqih merupakan faktor terpenting bagi kepentingan keberhasilan peserta didik.

Berkenaan dengan peran guru sebagai teladan, maka sebagaimana diungkapkan oleh bapak Abd. R Kaisuku selaku guru PAI di SMP Negeri 3 Taniwel bahwa:

Sebagai seorang guru memberikan contoh teladan yang baik kepada peserta didiknya. Seorang peserta didik akan lebih meniru apa yang gurunya ajarkan dibandingkan yang diajarkan oleh orang tuanya. Dan terkadang omongan orang tuanya tidak di pedulikan atau tidak digubris tetapi omongan guru sangat diperhatikan dan dilaksanakan oleh peserta didik. Untuk itu sebagai calon seorang guru harus membiasan berperilaku baik agar bisa menjadi bekal saat menjadi seorang guru. Guru juga harus memberikan contohcontoh perilaku yang baik kepada peserta didiknya agar peserta didiknya juga berperilaku baik. Karakter peserta didik itu akan terbentuk berdasarkan peran gurunya saat di sekolah. karena guru sebagai teladan untuk peserta didiknya. Jika menjadi seorang guru haruslah bisa menjadi teladan bagi peserta didiknya. Pemerintah juga menetapkan bahwa setiap anak berhak memperoleh pendidikan dan pengajaran dalam rangka pengembangan pribadinya dan tingkat kecerdasannya sesuai dengan minat dan bakatnya. jadi sebagai seorang guru haruslah bersifat sebaik mungkin agar bisa ditiru oleh peserta didiknya. hal itulah yang sering saya praktikkan dan saya lakukan setiap kali di sekolah.

Selain itu, penuturan bapak Abd. R Kaisuku selaku guru PAl di SMP Negeri 3 Taniwel selanjutnya bahwa:

Untuk bisa menjadi contoh yang baik buat peserta didik, bagi saya adalah selalu berupaya agar memberikan penampilan terbaik. Baik dari segi pengetahuan maupun dari segi penampilan dan tingkahlaku dan tutur kata baik di sekolah maupun di luar sekolah 
agar peserta didik bisa mencentohi tentang apa yang saya lakukan sehingga hal itu akan menjadi ukuran buat mereka. Jadi sebelum saya mengajar saya membaca al-Qur'an dengan betul dan menjadi contoh yang nantinya dapat mereka tiru. Tentu saya harus menunjukkan buat mereka yang baik agar menjadi panutan dan contoh yang mereka ambil dari seorang guru.

Di antara hal-hal penting yang dibutuhkan oleh seorang guru dalam mengatasi kesulitan membaca al-Qur'an pada peserta didik adalah mencari metode seperti petode qiraati untuk mengajarkan al-Qur'an kepada peserta didik mereka. Sebab, pengajaran al-Qur'an merupakan fondasi utama dalam Islam yang harus ditanamkan dalam diri anak-anak agar mereka tumbuh sesuai dengan fitrah dan hati mereka bersinar cerah tanpa dikeruhkan dengan gelapnya dosa dan maksiat.

Dari uraian di atas peneliti juga mewawancarai kepala sekolah terkait dengan peran guru sebagai teladan, sebagaimana diungkapkan oleh kepala sekolah bahwa:

Terdapat banyak cara dan metode yang dapat ditempuh dalam proses pendidikan dan pengajaran, namun hal yang sudah terbukti secara empiris paling baik dalam proses pengajaran dan penjabarannnya dalam kehidupan nyata, yaitu adannya guru sebagai suri tauladan atau panutan. Oleh karena itu, jika seorang guru ingin berperan dalam mengatasi kesulitan yang dialami oleh peserta didiknya dalam membaca al-Qur'an handaknya ia terlebih dahulu menanamkan rasa cinta peserta didiknya terhadap al-Qur'an. Dan seorang guru hendaknya menjadi teladan pertama bagi mereka.

Hal yang sama juga dikatakan pada saat mewawancarai guru PAI dalam Mengatasi Kesulitan peserta didik membaca al-Qur'an di SMP Negeri 3 Taniwel sebagai berikut:

Selaku guru PAI saya selalu memberi pemahaman terkait bagaimana cara agar kita bisa tuntas dalam membaca al-Qur'an, setidaknya kita sudah bisa membaca dengan baik sesuai dengan hukum bacaan yang berlaku. Dengan demikian saya selaku guru PAI selalu memberi penguatan yang membuat anak didik yang ada di SMP Negeri 3 Taniwel ini bisa lebih mengerti. Mengingat di zaman era moderen ini kita gampang dipengaruhi oleh orang lain dengan komunikasi dan alat canggih seperti alat elektronik lainnya. Untuk itu muatan-muatan yang mendorong peserta didik menjadi 
lebih baik dalam membaca al-Qur'an agar menjadi kekuatan moral dalam hidup mereka nantinya, hal ini selalu saya lakukan dan di dorong oleh guru dan kepala sekolah. Dan Alhamdulillah sebagian besar anak didik yang berada di SMP Negeri 3 Taniwel ini sangat baik dalam membaca al-Qur'an di sekolah maupun di luar jam sekolah. Hal ini bisa kita lihat sewaktu datang bulan suci ramadhan mereka sering melakukan tadarus di rumah-rumah maupun di sekolah.

Dari penuturan yang telah dikemukakan tersebut, maka dapat dikakatan bahwa guru adalah seseorang yang pekerjaannya mengajar. Maka, dalam hal ini guru PAI memberi pelajaran atau memberi materi Pendidikan Agama Islam pada peserta didik di kelas dengan cara dan perannya sebagai pengajar yang sebaik mungkin agar peserta didik mudah memahami apa yang disampaikan oleh guru PAI mengenai materi membaca al-Qur'an tersebut.

2. Faktor pendukung dan pemhambat guru pendidikan agama Islam dalam mengatasi kesulitan peserta didik membaca al-Qur'an di SMP Negeri 3 Taniwel Kecamatan Taniwel Barat, Kabupaten Seram

\section{Bagian Barat}

a) Faktor pendukung

Dari hasil penelitian yang dilakukan melalui wawancara dan informasi dari berbagai informan, maka dapat diketahui bahwa faktor yang mendukung peranan guru pendidikan agama Islam dalam mengatasi kesulitan peserta didik membaca al-Qur'an di SMP Negeri 3 Taniwel Kecamatan Taniwel Barat Kabupaten Seram Bagian Barat adalah sebagai berikut:

1) Sarana dan prasarana (media pembelajaran)

Media pembelajaran merupakan alat bantu yang memudahkan dalam aktivitas pembelajaran sehingga dengan adanya media yang memadai, maka ketercapaian dari tujuan pembelajaran dapat terlaksana dengan baik, begitu juga sebaliknya. Berkenaan dengan faktor pendukung yang berkaitan dengan peran guru agama Islam dalam mengatasi 
kesulitan membaca al-Qur'an di SMP Negeri 3 Taniwel, maka sebagaimana diungkapkan oleh guru, bahwa:

Saya banyak dibantu dengan media pembelajaran seperti ketersediaan buku sebagai referensi yang berkaitan dengan materi pelajaran yang tersedia di perpustakaan sekolah, saya juga mengarahkan dan terkadang menggunakan interenet sebagai media penunjang proses pembelajaran dan saya menyarankan kepada peserta didik untuk menggunakan media tersebut untuk lebih memahami materi yang dipelajari terkait dengan tatacara membaca al-Qur karena sudah banyak media elektronik yang mengajarkan tentang tatacara membaca al-Qur'an yang baik dan benar selain yang saya ajarkan berdasarkan materi di sekolah. Media belajar menurut saya adalah alat yang cukup membantu saya dalam menyamepaikan materi pelajran karena dengan media belajar tersebut saya tidak harus mengeluarkan banyak energi atau biasa untuk membuat atau membelinya. Media yang dimaksudkan adalam media buku sebagai sumber referensi dan media elektronik seperti laptop dan LCD projektor yang sudah dimiliki sekolah sehingga saya memanfaatkan untuk memudahkan proses pembelajran karena peserta didik akan lebih tertarik belajar dengan menggunakan media pembelajaran karena dapat melihat berbagai contoh yang berkaitna dengan materi yang diajarkan di kelas".

Berdasarkan penuturan dari informan tersebut terkait dengan penggunaan media pembelajaran, maka dapat disimpulkan bahawa dalam suatu proses belajar mengajar, dua unsur yang sangat penting adalah metode mengajar dan media pembelajaran. Kedua aspek ini saling berkaitan. Pemilihan salah satu metode mengajar tertentu akan mempengaruhi jenis media pembelajaran yang sesuai, meskipun masih ada berbagai aspek lain yang harus diperhatikan dalam memilih media pembelajaran, antara lain tujuan pembelajaran, jenis tugas dan respons yang diharapkan, termasuk karakteristik peserta didik.

2) Kesadaran guru dalam melaksanakan tanggung jawab

Kesadaran guru dalam melaksanakan tanggung jawab pada peserta didik di SMP Negeri 3 Taniwel. Kecamatan Taniwel Barat, Kabupaten Seram Bagian Barat merupakan faktor pendukung dalam meningkatkan pemahaman peserta didik sebagai berikut adalah ulasan guru PAI: 
Sebagai seorang guru, khusus saya selaku guru PAI. Saya selalu menjalankan tugas dan tanggung jawab sebagai seorang guru yaitu, mengajar dan mendidik peserta didik untuk menjadi lebih baik dalam membaca al-Qur'an, bukan hanya guru PAI saja akan tetapi guru yang lain juga memiliki tugas dan tanggung jawab yang sama. Karena maju mundurnya pendidikan ini juga didukung oleh kesadaran guru dalam melakukan tugas dan tanggung jawabnya.

Data di atas juga diperkuat dengan hasil observasi peneliti di sekolah SMP Negeri 3 Taniwel sebagai berikut:

Guru-guru SMP Negeri 3 Taniwel khusus guru PAI memiliki kesadaran dalam melakukan tanggung jawab sebagai seorang guru, hal ini dibuktikan dengan melaksanakan proses pembelajran dengan baik dan dengan penuh tanggung jawab kepada peserta didik dan selalu masuk sekolah meski tidak ada jadwal belajar mengajar terkait mata pelajarannya PAI.

3) Motivasi belajar peserta didik

Motivitasi atau kemauan dari diri peserta didik untuk belajar baik di sekolah maupun di rumah yang berkaitan dengan pembelajaran agama Islam. Oleh karena motivasi merupakan dorongan yang muncul baik dari dalam diri maupun dari luar diri (lingkungan dan lain sebagainya) untuk selalu berusaha tampil semaksimal mungkin berbuat yang terbaik. Hal ini sebagimana diungkapkan oleh guru bahwa:

"saya melihat banyak dalam diri peserta didik memiliki motivasi yang tingi dalam belajar pada mata pelajaran secara umum dan khususnya mata pelajaran PAI. Hal ini saya katakan karena banyak peserta didik yang selain belajar agama Islam khususnya pembacaan al-Qur'an selain di sekolah mereka lakukan juga di rumah yakni di TPA sehingga ketika disodorkan tentang membaca ayat al-Qur'an, maka peserta didik banyak yang bisa membaca dengan baik dan benar serta lancar berdasarkan makhraj huruf sehingga tujuan pembelajaran dan tercapai meskipun tidak semua peserta didik memiliki motivasi yang sama dalam belajar yang berkaitan dengan belajar membaca al-Qur'an."

Dari penuturan kedua informan di atas, maka sebagaimana hasil observasi peneliti melihat bahwa "dari sebagian besar peserta didik sudah timbul motivasi dalam dirinya untuk belajar al-Qur'an, terbukti ketika mereka antusia dalam membacakan ayat yang terdapat dalam materi atau 
menghafalkan surah yang terdapat dalam materi pelajaran atau surah pendek dengan lancar. Tetapi sebagian kecil dari peserta didik masih kurang adanya motivasi dalam dirinya, terbukti ketika menghafal masih ada yang mengalami kesulitan dalam membaca Al-Qur'an."

\section{b) Faktor Penghambat}

Selain faktor yang mendukung pasti ada faktor yang menghambat peranan guru pendidikan agama Islam dalam mengatasi kesulitan peserta didik membaca al-Qur'an di SMP Negeri 3 Taniwel Kecamatan Taniwel Barat Kabupaten Seram Bagian Barat, sebagaimana diungkapkan oleh. Abd. R Kaisuku selaku guru PAI mengemukakan, bahwa:

1) Kurangnya alokasi waktu

Berkenaan dengan faktor penghambat terkait dengan alokasi waktu dalam membaca al-Qur'an di SMP Negeri 3 Taniwel, maka dalam pelajaran PAI sangat kurang sekali mengingat belajar PAI membutuhkan waktu yang cukup banyak, seperti yang dikemukakan, bahwa:

"salah satu faktor penghambat peran guru agama Islam dalam mengatasi kesulitan peserta didik dalam membaca al-Qur'an untuk pelajaran PAI alokasi waktu 3 jam pelajaran, sedangkan pembelajaran tersebut tidak cukup waktunya namun mau bagaimana lagi karena sudah termuat dalam perubahan kurikulum K13 sehingga kami harus menyesuaiakan dengan mata pelajaran lainnya maka dirasa waktu tersebut kurang apalagi jumlah peserta didik dalam kelas terlalu banyak dengan waktu yang terbatas karena waktu disesuaikan dengan standar silabus dan RPP berdasarkan indikator dan tujuan pembelajaran yang akan dicapai."

Selanjutnya sebagaimana penuturan guru terkait dengan faktor penghambat, maka faktor penghambat tersebut juga disampaikan oleh oleh kepala sekolah, bahwa:

"salah satu faktor yang membuat proses pembelajaran terhambat adalah waktu, saya katakan demikian karena di sekolah ini sudah diberlakukan kurikulum 2013 (K13) sehingga semua waktu diatur sesuai dengan acuan silabus dan RPP pembelajaran sehingga pembagian waktu pada mata pelajaran khususnya agama terbatas yakni hanya berkisar $3 \mathrm{JP}$ (jam pelajarn) saja sehingga kami selaku guru PAI terkadang merasa kesulitan untuk penggunaan waktu 
yang terbatas sementara materi pada mata pelajaran PAI cukup banyak."

Berdasarkan uraian yang telah disampain terkait dengan faktor penghambat yang salah satu waktu pada mata pelajaran, maka dapat disimpulkan bahwa aktivitas belajar akan berlangsung baik bila waktu yang disedikan menjadi sangat banyak namun kendala terkait dengan peran guru agama Islam dalam mengatasi kesulitan membaca al-Qur'an di SMP Negeri 3 Taniwel, maka pembelajaran di SMP Negeri 3 Taniwel ini dalam pelajaran PAI sangat kurang sekali mengingat belajar PAI membutuhkan waktu yang cukup banyak. Sedangkan untuk pelajaran PAI alokasi waktu 3 jam pelajaran, sedangkan pembelajaran tersebut tidak cukup waktunya namun mau bagamana lagi karena sudah termuat dalam perubahan kurikulum K13 sehingga kami harus menyesuaiakan dengan mata pelajaran lainnya maka dirasa waktu tersebut kurang karena waktu disesuaikan dengan standar silabus dan RPP berdasarkan indikator dan tujuan pembelajaran yang akan dicapai.

2) Kurangnya perhatian orang tua

Sebagaimana telah dikemukakan di atas terkait dengan faktor penghambat yang menyebabkan peserta didik kesulitan belajar terutama yang berkitan dengan membaca al-Qur'an sebagaimana diungkapkan oleh guru bahwa:

"Masih ada hambatan yang berkaitan dengan proses pendidikan anak dalam belajar agama Islam khususnya dalam hal membaca al-Qur'an, karena selama ini saya melihat bahwa seakan orang tua menyerahkan proses pendidikan (agama) hanya kepada guru di sekolah, padahal itu dapat dilakukan proses permbelajaran agama (membaca al-Quir'an di lingkungan masyarakat dengan memasukan anak mereka ke TPQ/TPA) agar mereka dapat membaca al-Qur'an dengan baik dan benar disampiung diajarkan di sekolah, maka faktor yang terpenting adalah faktor orang tua yang kurang memperhatikan pendidikan anak, sehingga ketiak anak berada di sekolah dan ketika disuru membaca al-Qur'an anak tersebut terkadang gugup sehingga berdampak pada pengetahuan dan aktivitas mereka dalam mengikuti mata pelajaran agama Islam di SMP ini." 
Berdasarkan pemaparan dari informan di atas, terkait dengan hambatan peran guru agama Islam dalam mengatasi kesulitan membaca al-Qur'an di SMP Negeri 3 Taniwel, maka dapat diktakan bahwa kesadaran orang tua dengan aktivitas berlajar agama di lingkungan keluarga sehingga mejadikan anak mereka kurang dan bahkan terhambat dalam mempelajaran pendidikan agama Islam khususnya yang berkaitan dengan membaca Al-Qur'an. Olehnya itu, orang tua selaku orang yang bertanggung jawab penuh terhadap anaknnya ketika berada di rumah dan lingkungan masyarakat.

Berdasarkan uraian di atas, dapat dipahami bahwa faktor yang mendukung peranan guru pendidikan agama Islam dalam mengatasi kesulitan peserta didik membaca al-Qur'an Di SMP Negeri 3 Taniwel adalah faktor lingkungan baik internal maupun eksternal, sarana prasana termasuk media dan bahan ajar, kompetensi, sertifikasi dan orientasi kepemimpinan kepala sekolah. Sedangkan faktor yang menghambat peranan guru pendidikan agama Islam dalam mengatasi kesulitan peserta didik membaca al-Qur'an di SMP Negeri 3 Taniwel Kecamatan Taniwel Barat, Kabupaten Seram Bagian Barat. adalah, kurangnya guru PAI yang ada pada SMP Negeri 3 Taniwel. Kemudian guru honorer yang berada di SMP Negeri 3 Taniwel lebih banyak di bandingkan guru PNS. Dalam suatu lembaga pendidikan (sekolah) hubungan antara bawahan dan atasan apabila tidak ada komunikasi dan kerjasama yang baik pastilah akan berdampak pada peranan guru pendidikan agama Islam dalam mengatasi kesulitan peserta didik membaca al-Qur'an. Kompetensi guru yaitu kemampuan guru dalam mengelola kelas dan wawasan keilmuan seorang guru juga sangat berdampak pada peranan guru pendidikan agama Islam dalam mengatasi kesulitan peserta didik membaca al-Qur'an. Beban mengajar dengan jumlah ruang kelas yang tidak seimbang akan membuat guru tidak bisa mendidik, mengajar, membimbing, melatih, menilai dan mengevaluasi peserta didik dengan maksimal. 


\section{PEMBAHASAN}

\section{Peranan guru pendidikan agama Islam dalam mengatasi kesulitan peserta didik membaca AI-Qur'an Di SMP Negeri 3 Taniwel Kecamatan Taniwel Barat Kabupaten Seram Bagian Barat}

Berdasarkan hasil penelitian di lapangan peneliti memperoleh temuan penelitian bahwa guru PAI SMP Negeri 3 Taniwel memiliki peranan yang sentral dalam peranan guru pendidikan agama Islam dalam mengatasi kesulitan peserta didik membaca Al-Qur'an sebagai berikut:

a. Guru sebagai pengajar

Guru sebagai pengajar dalam hal ini yaitu guru mempunyai kepintaran khususnya dalam hal teori praktis untuk menjadi seorang guru yang professional. Guru adalah Tutor untuk anak didiknya. Seorang Tutor adalah seseorang yang mampu memberikan pembelajaran dengan teori yang ada secara fakta dan konseptual kepada para pendengar dan penikmat dalam teori yang dijelaskan oleh Tutor. Berarti dalam hal ini guru sebagai pengajar adalah guru yang memberikan pembelajaran kepada peserta didik atau peserta didik-peserta didiknya dengan teori-teori praktis, fakta dan konseptual.

Pengajar adalah menyampaikan, memberikan, mentransfer ilmu pengetahuan kepada peserta didik. Pengajaran hanya menekankan pada aspek pengetahuan, sehingga ketika peserta didik telah mengerti dan memahami materi pelajaran yang diajarkan maka pengajaran bisa dikatakan berhasil. Sehingga bagi seorang pengajar tidak begitu risau dengan sikap dan perilaku peserta didik-peserta didiknya, karena hal tersebut bukanlah merupakan tanggung jawabnya. seorang pengajar tidak mempersoalkan tentang tingkah lakunya, apakah tingkah laku mereka patut ditiru oleh peserta didik atau tidak. Mereka bisa melakukan hal-hal yang tidak sepantasnya dilakukan sebagai seorang panutan (Dede Rosyada, 2004:65)

Dalam hal ini seorang guru harus mampu menguasai materi yang akan diajarkan, dalam arti seorang guru harus memiliki kepintaran atau 
ahli dalam materi yang akan diajarkan kepada peserta didik. Dengan begitu guru harus mampu menguasai ilmu, antara lain mempunyai pengetahuan yang luas, menguasai bahan pelajaran, serta ilmu-ilmu yang bertalian dengan mata pelajaran atau bidang studi yang diajarkan, menguasai teori dan praktik mendidik, teori kurikulum metode pengajaran, teknologi pendidikan, teori evaluasi dan psikologi belajar dan sebagainya (Nana Sudjana, 2006:15).

Dengan demikian, maka dapat dikatakan bahwa guru sebagai pengajar diberikan keleluasaan untuk mengelola pembelajaran dan guru harus dapat menentukan pilihannya dengan mempertimbangkan semua aspek yang relevan atau menunjang tujuan yang hendak dicapai. Dalam hal ini guru bertindak sebagai pengambil keputusan. Ada beberapa hal yang harus dilakukan oleh seorang guru dalam pembelajaran, yaitu: membuat ilustrasi, mendefinisikan, menganalisis, bertanya, merespon, mendengarkan, menciptakan kepercayaan, memberikan pandangan yang bervariasi, menyediakan media untuk mengkaji materi standar, dan menyesuaikan metode pembelajaran. Agar pembelajaran memiliki kekuatan yang maksimal, guru harus senantiasa berusaha untuk mempertahankan dan meningkatkan semangat yang telah dimilikinya ketika mempelajari materi.

b. Guru sebagai pelatih

Guru sebagai pelatih dalam hal ini yaitu guru mempunyai skill khususnya dalam keterampilan untuk menjadi seorang guru yang professional. Pelaksanaan peran ini menuntut keterampilan tertentu yaitu mempunyai keteramplan dalam menyiapkan bahan ajar, keterampilan dalam menyampaikan ilmu kepada peserta didik, selain itu seorang guru berperan sebagai pelatih untuk dapat melahirkan generasi yang berkualitas maka guru harus mampu mengajar dan mengelolah administrasi yang berhubungan di sekolah. Seorang guru harus berfungsi sebagai pemelihara, pembina, pengasuh, dan pembimbing serta pemberi 
bekal ilmu pengetahuan, dan keterampilan kepada orang-orang yang membutuhkan secara umum, dan peserta didik secara khusus.

Proses pendidikan dan pembelajaran memerlukan latihan keterampilan, baik intelektual maupun motorik, sehingga menuntut guru untuk bertindak sebagai pelatih. Karena tanpa latihan tidak akan mampu menunjukkan penguasaan kompetensi dasar, dan tidak akan mahir dalam berbagai keterampilan yang dikembangkan sesuai dengan materi standar. sebagai pelatih, guru memberikan peluang yang sebesar-besarnya bagi peserta didik untuk mengembangkan cara-cara pembelajarannya sendiri sebagai latihan untuk mencapai hasil pembelajaran yang optimal (Abdurrahman An Nahwali, 2005:66).

Peran guru sebagai pelatih dapat dianalog kan sebagai peran pelatih sepak bola dalam setiap laga pertandingan sepak bola, yaitu peran dari para pelatih dalam meramu permainan timnya. Karena para pelatih inilah yang berdiri di luar lapangan. memberikan arahan serta strategi permainan. Ibarat sebuah organisasi, para pelatih ini merupakan seorang manajer di dalam organisasi tersebut yang memiliki peran di dalam pengorganisasian, penyeleksian, penempatan, penugasan, dan pemberian motivasi atau semangat kepada setiap orang di organisasi tersebut. Artinya, peran pelatih cukup vital, baik dalam membangun kerangka tim maupun menciptakan strategi permainan. Setiap pelatih pun dianjurkan memiliki kemampuan di dalam mencari atau melihat bakat, kemampuan, kelebihan serta kekurangan dari para pemainnya. Hal demikianlah, yang dijadikan dasar sang pelatih dalam menempatkan posisi masing-masing pemain serta tugas yang harus diemban si-pemain dalam setiap pertandingan guna menyokong strategi yang telah dibuatnya (Muhaimin, 2004:76).

Sehubungan dengan itu berkenaan dengan seorang guru, maka keterampilan ini berkaitan dengan kemampuan guru dalam menciptakan, membina dan memelihara hubungan intern yang harmonis di antara peserta didik dengan peserta didik, guru dengan peserta didik dan guru 
dengan guru. Dengan demikian di antara masing-masing pihak akan terjalin saling pengertian dan kerjasama yang baik dalam pelaksanaan tugas dan fungsi masing-masing sehingga dengan demikian akan menjamin kelancaran dalam proses belajar mengajar di dalam kelas. Sehubungan dengan itu seorang guru hendaknya mampu menerapkan prinsip-prinsip hubungan manusiawi di dalam kelas (Abdul Aziz, 2009:163) , yaitu :

1) Sinkronisasikan tujuan sekolah/kelas dengan tujuan peserta didik. Ini berarti guru selaku pimpinan harus berusaha mensinkronisasikan kepentingan sekolah/kelas dengan kepentingan peserta didik. Keberhasilan guru dalam melaksanakan tugasnya berarti terpenuhinya kebutuhan peserta didik. peserta didik diizinkan melakukan atau berbuat apa saja dalam mengembangkan dirinya sepanjang tidak merugikan kepentingan kelas/sekolah.

2) Ciptakan suasana belajar yang menyenangkan. Suasana belajar yang menyenangkan meliputi antara lain kegiatan belajar yang menarik,penuh tantangan dan tidak rutin, hubungan guru-peserta didik yang bersahabat, nuansa kelas yang membangkitkan motivasi belajar seperti kebersihan, keindahan, dan penataan ruangan.

3) Informalitas yang wajar dalam hubungan guru-peserta didik. Semakin baik manajemen kelas, hubungan guru- peserta didik semakin informal, tanpa melupakan segi formal. Jika informalitas terlalui merajai dalam hubungan guru-peserta didik, rasa hormat peserta didik terhadap guru dapat berkurang. Sebaliknya jika formalitas hubungan guru-peserta didik terlalu menonjol, maka kekakuan hubungan gurupeserta didik akan timbul yang mengakibatkan terganggu kelancaran peserta didik dalam belajar.

4) Jangan perlakukan peserta didik sebagai mesin. Berbeda dengan uang, mesin, metode, material, dan alat-alat kerja lainnya, peserta didik dalam belajar harus diperlakuan secara wajar. Kepribadiannya diakui, keinginannya diperhatikan. Peserta didik bukan benda mati 
yang dapat diperlakukan semaunya di luar batas-batas kemampuannya. Oleh karena itu guru dalam memberikan tugas-tugas belajar kepada peserta didik harus disesuaikan dengan batas-batas kemampuan manusiawinya.

5) Kembangkan kemampuan peserta didik sampai pada tingkat yang maksimal. Setiap orang dalam bekerja ingin mendapatkan kesempatan untuk mengembangkan dirinya, mereka ingin berprestasi, ingin maju, ingin kariernya berkembang. Oleh karenanya guru harus memberikan kesempatan kepada peserta didik untuk mewujudkan dirinya, merealisasikan potensi yang dimilikinya semaksimal mungkin dalam kegiatan belajar mengajar.

6) Buat kegiatan belajar yang menarik dan penuh tantangan. Belajar yang bersifat rutin cepat membosankan, sebaliknya belajar yang menarik dan penuh tantangan akan memperbesar gairah belajar, memperluas imajinasi dan memperhebat daya kereasi dan inisiatif. Sehubungan dengan itu guru harus mampu menciptakan kegiatan belajar mengakar yang menarik dan penuh tantangan bagi siwa-peserta didik sehingga dapat mendorong motivasi belajarnya.

7) Berikan pengakuan dan penghargaan atas pelaksanaan tugas dengan baik. Guru harus dapat mengakui dan menghargai pelaksanaan tugas dengan baik yang dilakukan oleh peserta didik.Bentuk pengakuan dan penghargaan itu dapat berupa pujian, ucapan terima kasih ataupun hadiah dan atau bentuk-bentuk lain.

8) Sediakan alat perlengkapan belajar yang cukup. Kurangnya lancarnya pelaksanaan tugas belajar, sering terjadi disebabkan oleh kurang tersedianya alat perlengkapan belajar yang diperlukan oleh peserta didik agar dapat melaksanakan tugasnya. Sehubungan dengan itu guru harus mengusahakan tersedianya alat perlengkapan belajar yang diperlukan peserta didik agar dapat melaksanakan tugasnya dengan baik, seperti buku-buku yang diperlukan. 
9) Memberikan imbalan atau penhargaan terhadap peserta didik yang berprestasi. Setiap peserta didik yang berprestasi di kelas harus diberikan imbalan atau penghargaan sesuai dengan prestasinya baik bersifat material maupun non material. Misalnya dengan memanggil nama peserta didik yang mendapat rangking kelas ke depan kelas pada saat menerima raport setiap akhir semester.

Dari bagan di atas jelas kepada kita bahwa keterampilan dalam berhubungan dengan sesamanya diperlukan dalam semua tingkatan management. Sedangkan keterampilan tehnical skill banyak diperlukan pada tingkat lower manager. Keterampilan conseptual skill banyak diperlukan pada tingkat Higher Manager. Dengan demikian dapat disimpulkan bahwa semakin tnggi kedudukan seseorang dalam suatu organisasi, semakin sedikit memerlukan tehnical skill dan semakin banyak memerlukan conseptual skill. Oleh karenanya dapat kita benarkan suatu teori yang menyatakan bahwa suksesnya seorang pemimpin organisasi bukan terletak pada tehnical skill, tetapi lebih ditentukan oleh managerial skillnya.

c. Guru sebagai teladan

Pada dasarnya perubahan perilaku yang dapat ditunjukkan oleh peserta didik harus dipengaruhi oleh latar belakang pendidikan dan pengalaman yang dimiliki oleh seorang guru, atau dengan perkataan lain guru mempunyai pengaruh terhadap perubahan perilaku peserta didik. Untuk itulah guru harus dapat menjadi contoh (suri tauladan) bagi peserta didik, karena pada dasarnya guru adalah representasi dari sekelompok orang pada suatu komunitas atau masyarakat yang diharapkan dapat menjadi teladan, yang dapat digugu dan ditiru (Hamzah B Uno, 2010:17).

Sebagai teladan, tentu saja pribadi dan apa yang dilakukan guru akan mendapat sorotan peserta didik serta orang disekitar lingkungannya yang menganggap atau mengakuinya sebagai guru. Sehubungan itu, beberapa hal yang perlu mendapat perhatian oleh para guru yaitu: sikap dasar, bicara dan gaya bicara, kebiasaan bekerja, sikap melalui 
pengalaman dan kesalahan, pakaian, hubungan kemanusiaan, proses berfikir, perilaku neurotis, selera, keputusan, kesehatan, gaya hidup secara umum (E Mulyasa, 2007:46).

Dari uraian tersebut, maka dapat dikatakan bahwa perilaku guru sangat mempengaruhi peserta didik, tetapi peserta didik harus bisa mengembangkan gaya hidup pribadinya sendiri. Guruyang baik adalah yang menyadari kesenjangan antara apa yang diinginkan dengan apa yang ada pada dirinya, kemudian menyadari kesalahan ketika memang bersalah. Kesalahan harus diikuti dengan sikap merasa dan berusaha untuk tidak mengulanginya lagi. Oleh karena itu guru perlu berusaha sekuat tenaga agar dapat menjadi teladan yang baik untuk peserta didik bahkan untuk seluruh masyarakat.

\section{Faktor pendukung dan penghambat Guru PAI dalam peranan guru} pendidikan agama Islam dalam mengatasi kesulitan peserta didik membaca al-Qur'an

Meskipun dalam peranan guru pendidikan agama Islam dalam mengatasi kesulitan peserta didik membaca al-Qur'an sudah sangat baik, Namun dalam proses mengatasi kesulitan membaca al-Qur'an peserta didik ada beberapa faktor pendukung dan penghambat.

\section{a. Faktor pendukung}

Adapun faktor pendukung peranan guru pendidikan agama Islam dalam mengatasi kesulitan peserta didik membaca al-Qur'an sebagai berikut:

1) Kesadaran guru dalam melaksanakan tanggung jawab

Guru adalah orang yang bertanggung jawab mencerdaskan kehidupan peserta didik. Pribadi susila yang cakap adalah yang diharapkan ada pada diri setiap peserta didik. Tidak ada seorang guru yang mengharapkan peserta didiknya menjadi sampah masyarakat. Untuk itulah guru dengan penuh dedikasi dan loyalitas berusaha membimbing dan membina peserta didik agar di masa mendatang menjadi orang yang berguna bagi nusa dan bangsa (Syamsu Yusuf, 2011:3). 
Setiap guru meluangkan waktu demi kepentingan peserta didik. Bila suatu ketika ada peserta didik yang tidak hadir di sekolah, guru menanyakan kepada peserta didik yang hadir, apa sebabnya dia tidak hadir ke sekolah. Peserta didik yang sakit, tidak bergairah belajar, terlambat masuk sekolah, belum menguasai bahan pelajaran, berpakaian sembarangan, berbuat yang tidak baik, terlambat membayar uang sekolah, tidak punya pakaian seragam, dan sebagainya, semuanya menjadi perhatian guru. Karena besarnya tanggung jawab guru terhadap peserta didiknya, hujan dan panas bukanlah menjadi penghalang bagi guru untuk selalu hadir di tengah-tengah peserta didiknya. Guru tidak pernah memusuhi peserta didiknya meskipun suatu ketika ada peserta didiknya yang berbuat kurang sopan pada orang lain. Bahkan dengan sabar dan bijaksana guru memberikan nasihat bagaimana cara bertingkah laku yang sopan dengan orang lain. Hal itu dilakukan karena profesinya sebagai seorang guru adalah berdasarkan panggilan jiwa, maka bila guru melihat peserta didiknya senang berkelahi, meminum minuman keras, menghisap ganja, dan sebagainya guru merasa sakit. Siang atau malam memikirkan bagaimana caranya agar peserta didiknya itu dapat dicegah dari perbuatan yang kurang baik, asusila dan amoral (Abdul Majid, 2011:126). Peserta didik lebih banyak menilai apa yang guru tampilkan dalam pergaulan di sekolah dan di masyarakat daripada apa yang guru katakan, tetapi baik perkataan maupun apa yang guru tampilkan keduanya menjadi penilaian peserta didik. Jadi, apa yang guru katakan harus dipraktikkan pula dalam kehidupan sehari-hari. Misalnya, guru memerintahkan kepada peserta didik agar hadir tepat pada waktunya.

Bagaimana peserta didik mematuhinya sementara guru sendiri tidak disiplin dengan apa yang pernah dikatakan. Perbuatan guru yang demikian, mendapat protes dari peserta didik. Guru tidak bertanggung jawab atas perbuatannya. peserta didik akhirnya tidak percaya lagi kepada guru dan mereka cenderung menentang perintahnya. Inilah sikap dan perbuatan yang ditunjukkan oleh peserta didik. 
Guru pada hakikatnya ditantang untuk senantiasa mengemban tanggung jawab moral dan tanggung jawab ilmiah agar kebudayaan nasional kita dapat bertahan identitasnya, disamping dapat berkembang atau progresif dalam kompetisinya dengan perkembangan budaya-budaya asing. Dengan tanggung jawab moral, guru dituntut untuk dapat mengejawantahkan nilai-nilai yang dijunjung tinggi oleh masyarakat, bangsa dan negara dalam diri pribadi, karena nilai-nilai itu harus senantiasa terpadu dengan diri orang yang menanamkan pada nilai agar usaha itu berhasil. Ini sesuai dengan prinsip kesesuaian antara apa yang dikatakan (baik) dengan apa yang dilakukan baik. Sedangkan tanggung jawab ilmiah, berkaitan dengan transformasi pengetahuan dan keterampilan yang saat ini menuntut guru senantiasa belajar untuk memperluas cakrawala dan perkembangan wawasan pengetahuannya sesuai dengan perkembangan-perkembangan yang mutakhir, disertai wawasan yang filosofis tentang pendidikan, sehingga pengambilan kebijakan atau keputusan dalam praktek pendidikan tidak meninggalkan makna hakikinya yaitu proses pemanusiaan manusia (Nurfuadi, 2012:56).

Dalam pembelajaran, guru sebagai pendidik berinteraksi dengan peserta didik yang mempunyai potensi beragam. Untuk itu, pembelajaran hendaknya lebih diarahkan pada proses belajar kreatif. Dalam kontek ini, guru lebih banyak berperan sebagai fasilitator daripada pengarah yang menentukan segala-galanya bagi peserta didik. Sebagai fasilitator guru lebih banyak mendorong peserta didik (motivator) untuk mengembangkan inisiatif dalam menjajagi tugas-tugas guru.

Tanggung jawab guru dalam menuntut peserta didik belajar yang terpenting adalah merencanakan dan melakukan kegiatan-kegiatan belajar guna mencapai pertumbuhan dan perkembangan yang diinginkan. Maka untuk mencapai cita-cita ideal tersebut dan agar pengajarannya berhasil, ada beberapa hal yang harus dilakukan oleh guru (Masnur Muslich, 2011:56-57), yaitu:

a. Mempelajari setiap peserta didik di kelasnya 
b. Merencanakan, menyediakan, dan menilai bahan-bahan belajar yang akan dan/telah diberikan

c. Memilih dan menggunakan metode mengajar yang sesuai dengan tujuan yang hendak dicapai, kebutuhan dan kemampuan peserta didik dan dengan bahan-bahan yang akan diberikan

d. Memelihara hubungan pribadi seerat mungkin dengan peserta didik

e. Menyediakan lingkungan belajar yang serasi

f. Membantu peserta didik dalam memecahkan berbagai masalah

g. Mengatur dan menilai kemajuan belajar peserta didik

h. Membuat catatan-catatan yang berguna dan menyusun laporan pendidikan

i. Mengadakan hubungan dengan orang tua peserta didik secara kontinu dan penuh saling pengertian

j. Mengadakan hubungan dengan masyarakat secara aktif dan kreatif guna kepentingan para peserta didik

dengan demikian, maka tanggung jawab guru tidak hanya menuangkan ilmu pengetahuan ke dalam otak speserta didik. Tapi yang terpenting adalah membentuk jiwa dan watak peserta didik. Sebab pendidikan dilakukan tidak semata-mata dengan perkataan, tetapi dengan sikap, tingkah laku, dan perbuatan. Peserta didik lebih banyak menilai apa yang guru tampilkan dalam pergaulan di sekolah dan di masyarakat daripada apa yang guru katakan, tapi baik perkataan maupun apa yang guru tampilkan, keduanya menjadi penilaian peserta didik. Oleh karena itu, apa yang dikatakan guru hendaknya dipraktikkan dalam kehidupan sehari-hari. Guru harus selalu menunjukkan sikap yang dapat diteladani oleh peserta didik.

2) Motivasi belajar peserta didik

Motivasi sangat berperan dalam belajar, peserta didik yang dalam proses belajar mempunyai motivasi yang kuat dan jelas pasti akan tekun dan berhasil belajarnya. Makin tepat motivasi yang diberikan, makin berhasil pelajaran itu. Adapun fungsi motivasi ada tiga, yaitu: 
a) Mendorong manusia untuk berbuat, jadi sebagai penggerak atau motor yang melepaskan energi.

b) Menentukan arah perbuatan yakni ke arah tujuan yang hendak dicapai.

c) Menyeleksi perbuatan yakni menentukan perbuatan-perbuatan apa yang harus dijalankan yang serasi guna mencapai tujuan itu dengan menyisikan perbuatan-perbuatan yang tidak bermanfaat bagi tujuan tersebut (Sardiman, 2020:17).

Sebagaimana yang telah dijelaskan di atas bahwa motivasi merupakan faktor yang mempunyai arti penting bagi peserta didik. Apalah artinya bagi seorang peserta didik pergi ke sekolah tanpa mempunyai motivasi belajar. Bahwa diantara sebagian peserta didik ada yang mempunyai motivasi untuk belajar dan sebagian lain belum termotivasi untuk belajar. Orang tua dalam melihat perilaku tersebut pada peserta didik, maka perlu diambil langkah-langkah untuk membangkitkan motivasi belajar mereka. Membangkitkan motivasi belajar mereka tidaklah muda, orang tua harus dapat menggunakan berbagai macam cara untuk memotivasi belajar peserta didik. Cara membangkitkan motivasi belajar diantaranya adalah:

a) Menjelaskan kepada peserta didik alasan suatu bidang studi dimasukan dan kegunaannya untuik kehidupan.

b) Mengkaitkan materi pelajaran dengan pengalaman peserta didik di luar.

c) Menunjukan antusias dalam mengajar.

d) Mendorong peserta didik untuk memadang belajar sebagai suatu tugas yang tidak harus serba menekan. Sehingga peserta didik mempunyai intensitas untuk belajar dan menjelaskan tugas dengan baik.

e) Menciptakan iklim dan suasana belajar sesuai dengan kebutuhan peserta didik.

f) Memberikan hasil ulangan dalam waktu sesingkat mungkin.

g) Menggunakan bentuk-bentuk kompetisi (persaingan). 
h) Menggunakan intensif seperti pujian dan hadiah secara wajar (Tadjab, 2004:103).

Seorang peserta didik yang akan menghadapi ujian dengan harapan dapat lulus, tentu akan melakukan kegiatan belajar dan tidak akan menghabiskan waktunya untuk bermain atau membaca komik, sebab tidak serasi dengan tujuan. Selain itu ada juga fungsi lain, yaitu motivasi dapat berfungsi sebagai pendorong usaha dan pencapaian prestasi, karena secara konseptual motivasi berkaitan dengan prestasi hasil belajar. Adanya motivasi yang baik dalam belajar akan menunjukan hasil yang baik. Dengan kata lain, adanya usaha yang tekun dan terutama didasari adanya motivasi, maka seorang yang akan belajar itu akan dapat melahirkan prestasi yang baik. Instrumen motivasi seorang peserta didik akan sangat menentukan tingkat pencapaian prestasi belajarnya. Ada beberapa bentuk dan cara untuk menumbuhkan motivasi dalam kegiatan belajar. Beberapa bentuk dan cara motivasi tersebut diantarnya memberi angka, hadiah, saingan/kompetisi, memberi ulangan, mengetahui hasil, pujian dan hukuman.

Demikian pembahasan tentang upaya dalam menumbuhkan motivasi belajar peserta didik dan bentuk-bentuk motivasi yang dapat dipergunakan oleh guru agar berhasil dalam proses belajar mengajar serta dikembangkan dan diarahkan untuk dapat melahirkan hasil belajar yang bermakna bagi kehidupan peserta didik.

\section{b. Faktor Penghambat}

Tidak dapat dipungkiri bahwa dalam proses pendidikan, bahwa kualitas pendidikan tersebut juga di dukung dengan sarana dan prasarana yang menjadi standar sekolah atau instansi pendidikan yang terkait. Sarana dan prasarana sangat mempengaruhi kemampuan peserta didik dalam belajar. Hal ini menunjukkan bahwa peranan sarana dan prasarana sangat penting dalam menunjang kualitas belajar peserta didik. Misalnya saja sekolah yang berada di kota yang sudah memiliki faslitas laboratorium komputer, maka anak didiknya secara langsung dapat belajar 
komputer sedangkan sekolah yang berada di desa tidak memiliki fasilitas itu dan tidak tahu bagaimana cara menggunakan komputer kecuali mereka mengambil kursus di luar sekolah.

Kurangnya alokasi waktu, berkenaan dengan faktor penghambat terkait dengan alokasi waktu dalam membaca al-Qur'an di SMP Negeri 3 Taniwel, salah satu faktor yang membuat proses pembelajaran terhambat adalah waktu, saya katakan demikian karena di sekolah ini sudah diberlakukan kurikulum 2013 (K13) sehingga semua waktu diatur sesuai dengan acuan silabus dan RPP pembelajaran sehingga pembagian waktu pada mata pelajaran khususnya agama terbatas yakni hanya berkisar 3 JP (jam pelajarn) saja sehingga kami selaku guru PAI terkadang merasa kesulitan untuk penggunaan waktu yang terbatas sementara materi pada mata pelajaran PAI cukup banyak.

Kurangnya perhatian orang tua, sebagaimana telah dikemukakan terkait dengan faktor penghambat yang menyebabkan peserta didik kesulitan belajar terutama yang berkitan dengan membaca al-Qur'an, kesadaran orang tua dengan aktivitas berlajar agama di lingkungan keluarga sehingga mejadikan anak mereka kurang dan bahkan terhambat dalam mempelajaran pendidikan agama Islam khususnya yang berkaitan dengan membaca Al-Qur'an. Olehnya itu, orang tua selaku orang yang bertanggung jawab penuh terhadap anaknnya ketika berada di rumah dan lingkungan masyarakat.

Berdasarkan uraian di atas, dapat dipahami bahwa faktor yang mendukung peranan guru pendidikan agama Islam dalam mengatasi kesulitan peserta didik membaca al-Qur'an Di SMP Negeri 3 Taniwel adalah faktor lingkungan baik internal maupun eksternal, sarana prasana termasuk media dan bahan ajar, kompetensi, sertifikasi dan orientasi kepemimpinan kepala sekolah. Sedangkan faktor yang menghambat peranan guru pendidikan agama Islam dalam mengatasi kesulitan peserta didik membaca al-Qur'an di SMP Negeri 3 Taniwel Kecamatan Taniwel Barat, Kabupaten Seram Bagian Barat. adalah, kurangnya guru PAI yang 
ada pada SMP Negeri 3 Taniwel. Kemudian guru honorer yang berada di SMP Negeri 3 Taniwel lebih banyak di bandingkan guru PNS. Dalam suatu lembaga pendidikan (sekolah) hubungan antara bawahan dan atasan apabila tidak ada komunikasi dan kerjasama yang baik pastilah akan berdampak pada peranan guru pendidikan agama Islam dalam mengatasi kesulitan peserta didik membaca Al-Qur'an. Kompetensi guru yaitu kemampuan guru dalam mengelola kelas dan wawasan keilmuan seorang guru juga sangat berdampak pada peranan guru pendidikan agama Islam dalam mengatasi kesulitan peserta didik membaca al-Qur'an. Beban mengajar dengan jumlah ruang kelas yang tidak seimbang akan membuat guru tidak bisa mendidik, mengajar, membimbing, melatih, menilai dan mengevaluasi peserta didik dengan maksimal. Jadi langkah pertama yang perlu dimiliki agar dapat belajar secara efektif dan efisien adalah kesadaran atas tanggung jawab pribadi dan keyakinan bahwa belajar adalah untuk kepentingan diri sendiri, dilakukan sendiri dan tidak menggantungkan nasib pada orang lain.

\section{KESIMPULAN}

Sesuai data hasil penelitian terkait dengan peranan guru pendidikan agama islam dalam mengatasi kesulitan peserta didik membaca al-Qur'an di SMP Negeri 3 Taniwel, maka dapat diambil kesimpulan bahwa:

1. Peranan guru pendidikan agama Islam dalam mengatasi kesulitan peserta didik membaca al-Qur'an SMP Negeri 3 Taniwel sebagai berikut:

a. Guru sebagai pengajar adalah seseorang yang pekerjaannya mengajar. Maka, dalam hal ini guru PAI memberi pelajaran atau memberi materi tentang membaca al-Qur'an pada peserta didik di kelas dengan cara dan perannya sebagai pengajar yang sebaik mungkin agar peserta didik mudah memahami apa yang disampaikan oleh guru PAI mengenai materi membaca al-Qur'an. 
b. Peran guru sebagai pelatih untuk menjadi seorang pelatih yang berhasil, maka guru PAI menjalankan perannya sebagai pelatih dengan kemampuannya yang profesional dalam meningkatkan pemahaman peserta didik melalui pelatihan-pelatihan yang diberikan guru PAl berupa tugas-tugas yang dikerjakan di rumah maupun berupa evaluasi yang dilakukan sehabis belajar untuk melatih kemampuan peserta didik dalam peningkatan pemahaman terhadap membaca al-Qur'an.

c. Guru sebagai teladan yang baik maka seorang guru harus memiliki kepribadian yang baik sehingga patut untuk dicontohkan oleh peserta didik. Perbuatan seorang guru sebagai teladan selalu menjadi sorotan utama kepada peserta didik karena selain guru sebagai teladan guru juga berperan sebagai pembimbing

2. Faktor pendukung dan penghambat adalah untuk mengetahu bagaimana Peranan guru Pendidikan Agama Islam Dalam Mengatasi Kesulitan peserta didik Membaca al-Qur'an di SMP Negeri 3 Taniwel. Adapun faktor pendukung Dalam Mengatasi Kesulitan peserta didik Membaca al-Qur'an adalah:

a. Faktor pendukung pelaksanaan tugas atau peranan guru pendidikan agama islam adalah; 1) Sarana dan prasarana (media pembelajaran), 2) Kesadaran guru dalam melaksanakan tanggung jawab, dan 3) Motivasi belajar peserta didik.

b. Faktor yang menghambat peranan guru pendidikan agama Islam dalam mengatasi kesulitan peserta didik membaca al-Qur'an di SMP Negeri 3 Taniwel Kecamatan Taniwel Barat Kabupaten Seram Bagia yaitu; 1) Kurangnya alokasi waktu dan 2) Kurangnya perhatian orang tua.

\section{DAFTAR PUSTAKA}

[1] Syamsu Yusuf. Juntika Nurihsan. Teori Kepribadian. Bandung: PT. Remaja Rosdakarya, 2011. 
[2] A.M., Sardiman. Interaksi dan Motivasi Belajar. Cet. XII, Jakarta: Rajawali, 2000.

[3] Abdul Aziz, Filsafat Pendidikan Islam. Yogyakarta, Teras, 2009.

[4] Abdullah. Pengembangan Kurikulum Teori dan Praktek. Yogyakarta: Raja Grafindo Persada, 2011.

[5] Ahmadi, Abu, Widodo Supriyono, Psikologi Belajar, Jakarta: Geman Insani Press, 2008.

[6] Ali, H. Muhammad. Guru Dalam Proses Belajar Mengajar. Bandung: Pustaka Pelajar, 2004.

[7] al-Qattan, Manna' Khalil. Studi IImu-IImu Qur'an. Jakarta: Gema Insani Press. 2004.

[8] al-Syeikh, Syeikh Saleh ibn Abdul Aziz ibn Muhammad. Al-Qur'an dan terjemahanya, (Madinah Al- Munawaroh: Mujamma' Malik Fahd li Thiba'at Al- Mushaf Asy-Syarif, t.t.

[9] An Nahlawi, Abdurrahman. Pendidikan Islam di Rumah, Sekolah, dan Masyarakat. Gema Insani Press: Jakarta, 2005.

[10] Arif, Arifudin. Pengantar IImu Pendidikan Islam, Jakarta: Raja Grafindo Persada. 2008.

[11] Asmani, Jamal Ma'mur. Tips Menjadi Guru Inspiratif, Kreatif, dan Inovatif. Yogyakarta, 2013.

[12] Assegaf, Abd. Rachman. Studi Islam Kontekstual. Yogyakarta: Gema Insani Press, 2005.

[13] Daradjat, Zakiah. IImu Pendidikan Islam. Jakarta: Gema Insani Press, 2014.

[14] Hamalik, Oemar. Proses Belajar Mengajar, Jakarta: Gema Insani Press, 2011.

[15] Hanifah. Peran Guru Dalam Mengatasi Kesulitan Membaca AlQur'an Peserta didik di SMPIslam Al-lkhlas Cipete Jakarta Selatan; Skripsi. Jakarta: 2011.

[16] Hasim, Iris Gunawan. Kajian Global Al-Qur'an. Sidoarjo, 2008.

[17] Hermawan, Acep. Metodologi Pembelajaran Bahasa Arab. Bandung: Gema Insani Press, 2011.

[18] Indrawan, Irjus. Pengantar Manajemen Sarana Dan Prasarana Sekolah. Jakarta: Raja Grafindo Persada, 2001.

[19] Khalil, Moenawar. Al-Qur'andari Masa ke Mas. Solo. 2005.

[20] Majid, Abdul. Perencanaan Pembelajaran (Mengembangkan Standar Kompetensi Guru). Bandung: PT Remaja Rosdakarya, 2011.

[21] Muhaimin. Nuansa Baru Pendidikan Islam. Jakarta: Raja Grafindo Persada, 2006.

[22] Mulyasa, E. Menjadi Guru Profesional. Bandung: PT Remaja Rosdakarya, 2007.

[23] Muslich, Masnur. Pendidikan Karakter: Menjawab Tantangan Krisis Multidimensional. Jakarta: Bumi Aksara, 2011

[24] Nurfuadi. Profesionalisme Guru. Purwokerto: STAIN Pres, 2012.

[25] Riyadh, Sa'ad. Anakku, Cintailah Al-Qur'an. Jakarta: Rineka Cipta 2007. 
[26] Rosyada, Dede. Paradigma Pendidikan Demokrasi. Cet. I, Jakarta: Kencana, 2004.

[27] Slameto. Belajar Dan Faktor-Faktor Yang Mempengaruhi. Jakarta: Pustaka Pelajar, 2013.

[28] Subini, Nini. Mengatasi Kesulitan Belajar Pada Anak. Jogyakarta: Pustaka Pelajar, 2011.

[29] Sudjana, Nana. Cara Belajar Siswa Aktif. Cet. III. Bandung: Sinar Baru Algesindo, 2006.

[30] Suparlan. Menjadi Guru Efektif. Yogyakarta: Hikayat Publishing, 2005.

[31] Syam, Yunus Hanis. Fasih Baca al-Qur'an. Yogyakarta: Raja Grafindo Persada, 2008.

[32] Tadjab. IImu Jiwa Pendidikan. Cet. I, Surabaya: Karya Abitama, 2004.

[33] Taqwim, Umar. 7 1/2 Jam Bisa Membaca Al-Qur'an. Sukoharjo: Sinar Baru Algensindo Offset, 2013:

[34] Thabathaba'i, Sayyid Muhammad Husain. Memahami Esensi AlQur'an diterjemahkan dari Al-Qur'an fi al-Islam oleh Idrus Alkaf. Jakarta: Pustaka Pelajar, 2000.

[35] Uno, Hamzah B. Profesi Kependidikan: Problema, Solusi, dan Reformasi Pendidikan di Indonesia. Jakarta: PT Bumi Aksara, 2010.

[36] Usman. Metafora al-Qur'an Dalam Nilai-Nilai Pendidikan dan Pengajaran. Yogyakarta, 2010. 